\title{
Secondary Metabolites of Hypericum L. Species as Xanthine Oxidase Inhibitors
}

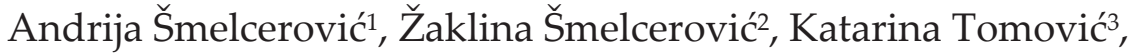 \\ Gordana Kocić, ${ }^{4}$ Aleksandra Đorđevićs \\ ${ }^{1}$ University of Niš, Faculty of Medicine, Department of Chemistry, Niš, Serbia \\ 2 University of Niš, Faculty of Medicine, Center for Biomedicinal Science, Niš, Serbia \\ ${ }^{3}$ University of Niš, Faculty of Medicine, Department of Pharmacy, Niš, Serbia \\ ${ }^{4}$ University of Niš, Faculty of Medicine, Institute of Biochemistry, Niš, Serbia \\ ${ }^{5}$ University of Niš, Faculty of Science and Mathematics, Department of Chemistry, Niš, Serbia
}

\section{SUMMARY}

Nine Hypericum species (H. barbatum, H. hirsutum, H. linarioides, H. olympicum, H. perforatum, $H$. rochelii, $\mathrm{H}$. rumeliacum, $\mathrm{H}$. tetrapterum and $\mathrm{H}$. umbellatum) collected in Serbia were assayed for inhibitory potential against xanthine oxidase in vitro, on the commercial enzyme, and compared with allopurinol. Seven studied Hypericum species (H. barbatum, H. rochelii, $H$. rumeliacum, H. umbellatum, $H$. perforatum, $H$. tetrapterum and $H$. olympicum) inhibit commercial xanthine oxidase with an $\mathrm{IC}_{50}$ below $100 \mu \mathrm{g} / \mathrm{mL}$. $H$. barbatum exerted the most potent inhibitory effect $\left(\mathrm{IC}_{50}=31.84 \pm 6.64 \mu \mathrm{g} / \mathrm{mL}\right)$, followed closely by $H$. perforatum $\left(\mathrm{IC}_{50}=37.12 \pm 4.06 \mu \mathrm{g} / \mathrm{mL}\right)$.

Key words: xanthine oxidase inhibition, Hypericum, secondary metabolites

Corresponding author:

Andrija Šmelcerović

E-mail: a.smelcerovic@yahoo.com 


\section{INTRODUCTION}

Xanthine oxidase $(\mathrm{XO})$ is a validated target for therapeutic treatment of gout, hyperuricemia and associated conditions, with a few $\mathrm{XO}$ inhibitors present on the market (1). Levels of XO in plasma are enhanced also in ischemia-reperfusion injury, hemorrhagic shock, cholecystis, hypercholesterolemia, adult respiratory distress syndrome, carcinogenesis, which provides additional indications where $\mathrm{XO}$ inhibitors may exert their therapeutic potential (2).

Secondary metabolites from plants have a long tradition of being used as therapeutics in medicine (3). Hypericum species are traditionally used as medicinal plants all over the world (4). H. perforatum (St. John's wort) is one of the best chemically determined species. The investigation of Hypericum species have increased over the years due to evidenced bioactivities of compounds found in $H$. perforatum. Chemically, naphthodianthrones, primarily hypericin and pseudohypericin, phloroglucinol derivatives, especially hyperforin, and flavonoids quercetin, quercitrin, hyperoside and rutin represent the main constituents in the Hypericum species (5).

Continuing our research on the chemical composition (6-11) and pharmacological activities (11-14) of Hypericum species, in the present study extracts of nine Hypericum species $(H$. barbatum, H. hirsutum, $H$. linarioides, $H$. olympicum, $H$. perforatum, $H$. rochelii, $H$. rumeliacum, $H$. tetrapterum and $H$. umbellatum), collected in Serbia, were evaluated for inhibitory potential against $\mathrm{XO}$ in vitro, on the commercial enzyme.

\section{MATERIALS AND METHODS}

\section{Plant material}

Table 1 contains data on the identity of nine assayed Hypericum species, their taxonomic placement within sections of the genus Hypericum, voucher numbers of the deposited herbarium specimens (Herbarium Moesicum Doljevac, Serbia), collection period and locality (15). Collection was done in the blooming stage.

Table 1. Data on the assayed Hypericum species

\begin{tabular}{|c|c|c|c|c|}
\hline Section & Plant species & $\begin{array}{c}\text { Voucher } \\
\text { number (HMD) }\end{array}$ & $\begin{array}{c}\text { Collection } \\
\text { period }\end{array}$ & Locality \\
\hline \multirow{4}{*}{$\begin{array}{c}\text { Drosocarpium } \\
\text { Spach }\end{array}$} & H. barbatum & 7280 & August 2010 & $\begin{array}{c}\text { Suva planina, } \\
\text { East Serbia }\end{array}$ \\
\hline & H. rochelii & 6578 & July 2010 & $\begin{array}{l}\text { Sokobanja, } \\
\text { East Serbia }\end{array}$ \\
\hline & H. rumeliacum & 7287 & July 2010 & $\begin{array}{c}\text { Suva planina, } \\
\text { East Serbia }\end{array}$ \\
\hline & H. umbellatum & 6579 & July 2010 & $\begin{array}{c}\text { Surroundings of } \\
\text { Pirot, South East } \\
\text { Serbia }\end{array}$ \\
\hline \multirow[t]{2}{*}{ Hypericum } & H. perforatum & 7291 & July 2010 & $\begin{array}{c}\text { Surroundings } \\
\text { of Leskovac, } \\
\text { South Serbia }\end{array}$ \\
\hline & H. tetrapterum & 8223 & July 2010 & $\begin{array}{c}\text { Bosilegrad, } \\
\text { South East Serbia }\end{array}$ \\
\hline Olympia Spach & H. olympicum & 7288 & July 2010 & $\begin{array}{l}\text { Rujan planina, } \\
\text { South Serbia }\end{array}$ \\
\hline \multirow{2}{*}{$\begin{array}{l}\text { Taeniocarpium } \\
\text { Jaub. \& Spach }\end{array}$} & H. hirsutum & 7282 & July 2010 & $\begin{array}{c}\text { Suva planina, } \\
\text { East Serbia }\end{array}$ \\
\hline & H. linarioides & 8224 & July 2010 & $\begin{array}{c}\text { Suva planina, } \\
\text { East Serbia }\end{array}$ \\
\hline
\end{tabular}




\section{Preparation of plant extracts}

The extractions were performed using $3 \mathrm{~g}$ dry plant material and $30 \mathrm{~mL}$ of ethanol, using an indirect sonication method. Sonications lasted $30 \mathrm{~min}$, using a Bandelin Sonorex Digital 10 P apparatus (Bandelin). At the end of extraction, filtration was done in order to separate the extracts from the residual plant material. After washing the residues with $15 \mathrm{~mL}$ of ethanol, the filtrates were combined and evaporated using a rotary vacuum evaporator Büchi® Rotavapor ${ }^{\circledR}$ R-210 (Büchi). Dry extracts were then dissolved in dimethyl sulfoxide (DMSO) and stored at $-20^{\circ} \mathrm{C}$ until measurement.

\section{Evaluation of xanthine oxidase inhibition}

Inhibition of $\mathrm{XO}$ was evaluated in vitro on the commercial bovine milk enzyme (Sigma-Aldrich), by spectrophotometric measurement of uric acid formation at $293 \mathrm{~nm}$. The assay was performed in a series of testtubes (total volume $2150 \mu \mathrm{L}$ ) prepared in the following order: i) Test samples: 0.01 units of $\mathrm{XO}$, one of the studied extracts diluted in DMSO (purity $\geq 99.5 \%$; Sigma-Aldrich) (the final concentration of DMSO in the assay was $4.65 \% \mathrm{v} / \mathrm{v}$ ), $232.5 \mu \mathrm{M}$ of xanthine (purity $\geq$ 99.5\%; Sigma-Aldrich), and $46.5 \mathrm{mM}$ TRIS-HCl buffer (pH 7.8); ii) Solvent control samples: the same amount of $\mathrm{XO}$, appropriate amount of DMSO, xanthine and TRIS$\mathrm{HCl}$ buffer; iii) Control samples: the same amount of $\mathrm{XO}$, xanthine and TRIS-HCl buffer adjusted to the same volume. Blank samples were prepared for each group (iiii). The tubes were incubated at $37^{\circ} \mathrm{C}$ for $15 \mathrm{~min}$, and after that the reaction was stopped by adding $100 \mu \mathrm{L}$ of perchloric acid. The difference in absorbance, calculated as a percent change of the control with appropriate amount of DMSO, which correlates to uric acid formation, was used for the determination of the percentage of enzyme inhibition. DMSO, at a final concentration of $4.65 \% \mathrm{v} / \mathrm{v}$, did not affect the enzyme assay. The evaluation of $\mathrm{XO}$ inhibitory potential of all samples was performed at the concentrations of 100 $\mu \mathrm{g} / \mathrm{mL}$. Extracts exerting inhibition greater than $50 \%$ at $100 \mu \mathrm{g} / \mathrm{mL}$ were tested in a broader concentration range in order to allow calculation of IC 50 values. Each $\mathrm{IC}_{50}$ curve was generated using four concentrations of inhibitor producing an inhibition. Positive control was allopurinol and experiments were performed in triplicate.

\section{RESULTS AND DISCUSSION}

Seven of the nine studied Hypericum species inhibit commercial bovine milk $\mathrm{XO}$ with an $\mathrm{IC}_{50}$ below $100 \mu \mathrm{g} / \mathrm{mL}$ (Table 2). H. barbatum showed the most potent inhibitory effect $\left(\mathrm{IC}_{50}=31.84 \pm 6.64 \mu \mathrm{g} / \mathrm{mL}\right)$. Allopurinol, an approved $\mathrm{XO}$ inhibitor, exhibited stronger inhibitory potential $\left(\mathrm{IC}_{50}=0.20 \pm 0.03 \mu \mathrm{g} / \mathrm{mL}\right.$ ) than studied Hypericum species. The extracts of Hypericum species belonging to the section Taeniocarpium did not inhibit commercial bovine milk XO with an $\mathrm{IC}_{50}$ below $100 \mu \mathrm{g} / \mathrm{mL}$.

Table 2. Inhibitory activities of studied Hypericum species against bovine milk xanthine oxidase ( $\left.\mathrm{IC}_{50}, \mu \mathrm{g} / \mathrm{mL}\right)$

\begin{tabular}{l|l|c}
\hline \hline \multicolumn{2}{c|}{ Allopurinol } & $0.20 \pm 0.03$ \\
\hline \multicolumn{1}{c|}{ Section } & \multicolumn{1}{|c}{ Plant species } & IC50 $(\mu \mathrm{g} / \mathbf{m L}) \mathbf{X O}$ \\
\hline Drosocarpium Spach & & \\
\hline \multirow{2}{*}{ Hypericum } & H. barbatum & $31.84 \pm 6.64$ \\
\cline { 2 - 3 } & H. rochelii & $42.78 \pm 9.32$ \\
\cline { 2 - 3 } & H. rumeliacum & $43.70 \pm 5.85$ \\
\cline { 2 - 3 } & H. umbellatum & $41.40 \pm 7.14$ \\
\hline Olympia Spach & H. perforatum & $37.12 \pm 4.06$ \\
\cline { 2 - 3 } Taeniocarpium Jaub. \& Spach & H. tetrapterum & $48.77 \pm 7.21$ \\
\cline { 2 - 3 } & H. olympicum hirsutum & $64.76 \pm 9.14$ \\
\cline { 2 - 3 } & H. linarioides & $>100$ \\
\hline \hline
\end{tabular}


Benedí et al. (16) determined IC50 $68.30 \mu \mathrm{g} / \mathrm{mL}$ for the hydroethanolic standardized extract of $H$. perforatum (0.3\% total hypericins), while Havlik et al. (17) determined $\mathrm{IC}_{50} 46.70 \mu \mathrm{g} / \mathrm{mL}$ for the $80 \%$ aqueous ethanolic extract of $H$. perforatum and $\mathrm{IC}_{50} 55.40 \mu \mathrm{g} / \mathrm{mL}$ for the methylene chloride - methanolic (50/50 $\mathrm{CH}_{2} \mathrm{Cl}_{2} / \mathrm{MeOH}$ ) extract of $H$. perforatum.

We found earlier that there is a strong correlation between secondary metabolite contents and the infrageneric classification of Robson (15) among the nine Hypericum species $(H$. barbatum, $H$. hirsutum, $H$. linarioides, $H$. maculatum, $H$. olympicum, $H$. perforatum, $H$. richeri, $H$. rumeliacum and $H$. tetrapterum), collected on different locations in Serbia and the F.Y.R. Macedonia (6). It was shown that $H$. barbatum possesses higher (3.9 times) content of hypericin than $H$. perforatum (6), which is in agreement with the study of Kitanov (18), who reported that the content of total hypericins in $H$. barbatum is by 2.4 times higher than in H. perforatum. The potent inhibitory effect of $H$. barbatum against $\mathrm{XO}$ activity may be related to the high level of hypericin. Also, $H$. perforatum showed a very potent inhibitory effect against $\mathrm{XO}$ with an $\mathrm{IC}_{50}$ value of $37.12 \pm 4.06$ $\mu \mathrm{g} / \mathrm{mL}$. The highest content of hyperforin was found in H. perforatum (6).

\section{CONCLUSION}

Ethanolic extracts of $H$. barbatum, $H$. rochelii, $H$. rumeliacum, $H$. umbellatum, $H$. perforatum, $H$. tetrapterum and $H$. olympicum inhibit commercial bovine milk $\mathrm{XO}$ with an $\mathrm{IC}_{50}$ below $100 \mu \mathrm{g} / \mathrm{mL}$. H. barbatum showed the highest inhibitory activity and may be potentially used in the treatment of hyperuricemia and gout.

\section{Acknowledgements}

The financial support of this work by Ministry of Education, Science and Technological Development of the Republic of Serbia (Grants No. OI 172044 and TR 31060) and internal project of Faculty of Medicine, University of Niš no. 4 is gratefully acknowledged. 


\section{References}

1. Lü JM, Yao Q, Chen C. 3,4-Dihydroxy-5nitrobenzaldehyde (DHNB) is a potent inhibitor of xanthine oxidase: a potential therapeutic agent for treatment of hyperuricemia and gout. Biochem Pharmacol 2013; 86(9): 1328-37.

https://doi.org/10.1016/j.bcp.2013.08.011

2. Radi R, Rubbo H, Bush K, Freeman B. Xanthine oxidase binding to glycosaminoglycans: kinetics and superoxide dismutase interactions of immobilized xanthine oxidase-heparin complexes. Arch Biochem Biophys 1997; 339: 125-35.

https://doi.org/10.1006/abbi.1996.9844

3. Hufsky F, Scheubert K, Böcker S. New kids on the block: novel informatics methods for natural product discovery. Nat Prod Rep 2014; 31: 807-17. https://doi.org/10.1039/c3np70101h

4. Yazaki K, Okuda T. Medicinal and aromatic plants VI. In: Bajaj, Y.P.S. (ed), Biotechnology in agriculture and forestry. Springer-Verlag, Berlin, 1994: 167-78.

5. Stojanović G, Đorđević A, Šmelcerović A. Do other Hypericum species have medical potential as St. John's Wort (Hypericum perforatum)? Curr Med Chem 2013; 20: 2273-95.

https://doi.org/10.2174/0929867311320180001

6. Smelcerovic A, Spiteller M. Phytochemical analysis of nine Hypericum L. species from Serbia and the F.Y.R. Macedonia. Pharmazie 2006; 61: 251-2.

7. Smelcerovic A, Verma V, Spiteller $M$, et al. Phytochemical analysis and genetic characterisation of six Hypericum species from Serbia. Phytochemistry 2006; 67: 171-7. https://doi.org/10.1016/j.phytochem.2005.10.021

8. Smelcerovic A, Spiteller M, Ligon AP, et al. Essential oil composition of Hypericum L. species from Southeastern Serbia and their chemotaxonomy. Biochem Syst Ecol 2007; 35: 99-113. https://doi.org/10.1016/j.bse.2006.09.012
9. Verma V, Smelcerovic A, Zuehlke S, et al. Phenolic constituents and genetic profile of Hypericum perforatum L. from India. Biochem Syst Ecol 2008; 36: 201-6.

https://doi.org/10.1016/j.bse.2007.09.003

10. Smelcerovic A, Zuehlke S, Spiteller M, et al. Phenolic constituents of 17 Hypericum species from Turkey. Biochem Syst Ecol 2008; 36: 316-9. https://doi.org/10.1016/j.bse.2007.09.002

11. Đorđević A, Lazarević J, Šmelcerović A, Stojanović G. The case of Hypericum rochelii Griseb. \& Schenk and Hypericum umbellatum A. Kern. essential oils: Chemical composition and antimicrobial activity. J Pharm Biomed Anal 2013; 77: 145-8. https://doi.org/10.1016/j.jpba.2013.01.024

12. Radulović N, Stankov-Jovanović V, Stojanović G, et al. Screening of in vitro antimicrobial and antioxidant activity of nine Hypericum species from the Balkans. Food Chem 2007; 103: 15-21. https://doi.org/10.1016/j.foodchem.2006.05.062

13. Bonkanka CX, Smelcerovic A, Zuehlke S, et al. HPLC-MS analysis and anti-oedematogenic activity of Hypericum grandifolium Choisy (Hypericaceae). Planta Med 2008; 74: 719-25. https://doi.org/10.1055/s-2008-1074526

14. Spiteller M, Özen T, Smelcerovic A, et al. Phenolic constituents and the in vitro antioxidant activity of the flowers of Hypericum venustum. Fitoterapia 2008; 79: 191-3.

https://doi.org/10.1016/j.fitote.2007.11.012

15. Robson NKB. Studies in the genus Hypericum L. (Guttiferae) I. Infrageneric classification. Bull Br Mus Nat Hist (Botany) 1977; 5: 293-355.

16. Benedí J, Arroyo R, Romero C, et al. Antioxidant properties and protective effects of a standardized extract of Hypericum perforatum on hydrogen 
peroxide-induced oxidative damage in PC12 cells. Life Sci 2004; 75: 1263-76.

https://doi.org/10.1016/j.lff.2004.05.001

17. Havlik J, Gonzalez de la Huebra R, Hejtmankova K, et al. Xantine oxidase inhibitory properties of Czech medical plants. J Ethnopharmacol 2010; 132: 461-5.

https://doi.org/10.1016/j.jep.2010.08.044

18. Kitanov GM Hypericin and pseudohypericin in some Hypericum species. Biochem Syst Ecol 2001; 29: 171-8.

https://doi.org/10.1016/S0305-1978(00)00032-6 


\title{
Inhibicija ksantin-oksidaze sekundarnim metabolitima iz biljnih vrsta roda Hypericum L.
}

\author{
Andrija Šmelcerović ${ }^{1}$, Žaklina Šmelcerovićn ${ }^{2}$ Katarina Tomović3, \\ Gordana Kocićn ${ }^{4}$ Aleksandra Đorđevićs \\ ${ }^{1}$ Univerzitet u Nišu, Medicinski fakultet, Katedra za hemiju, Niš, Srbija \\ ${ }^{2}$ Univerzitet $u$ Nišu, Medicinski fakultet, Naučnoistraživački centar za biomedicinu, Niš, Srbija \\ ${ }^{3}$ Univerzitet u Nišu, Medicinski fakultet, Katedra za farmaciju, Niš, Srbija \\ ${ }^{4}$ Univerzitet u Nišu, Medicinski fakultet, Katedra za biohemiju, Niš, Srbija \\ ${ }^{5}$ Univerzitet $u$ Nišu, Prirodno matematički fakultet, Departman za hemiju, Niš, Srbija
}

\section{SAŽETAK}

Ispitan je uticaj devet Hypericum vrsta $(H$. barbatum, $H$. hirsutum, $H$. linarioides, $H$. olympicum, $H$. perforatum, $H$. rochelii, $H$. rumeliacum, $H$. tetrapterum i $H$. umbellatum) prikupljenih na području Srbije na aktivnost komercijalne ksantin-oksidaze in vitro i upoređena sa alopurinolom. Sedam ispitivanih Hypericum vrsta $(H$. barbatum, $H$. rochelii, $H$. rumeliacum, $H$. umbellatum, $H$. perforatum, $H$. tetrapterum i $H$. olympicum) inhibiraju komercijalnu ksantin-oksidazu sa IC 50 vrednostima nižim od $100 \mu \mathrm{g} / \mathrm{mL}$. H. barbatum (IC50 = 31,84 \pm $6,64 \mu \mathrm{g} / \mathrm{mL}$ ) i $H$. perforatum (IC50 $=37,12 \pm 4,06 \mu \mathrm{g} / \mathrm{mL}$ ) su se pokazali kao najefikasniji inhibitori ksantinoksidaze.

Ključne reči: inhibicija ksantin-oksidaze, Hypericum, sekundarni metaboliti 